\title{
Shadowing a Woman Administrator: A Turkish Case
}

\author{
Ramazan Asar ${ }^{1, *}$, Yeliz Çelikten ${ }^{2}$ \\ ${ }^{1}$ Kutalmisbey Secondary School, Turkey \\ ${ }^{2}$ Kepez Primary School, Turkey
}

Copyright $(2016$ by authors, all rights reserved. Authors agree that this article remains permanently open access under the terms of the Creative Commons Attribution License 4.0 International License

\begin{abstract}
Turkey has a strong centralized education system in which all the decision-making is done by the Ministry of National Education. The education is mostly based on a traditional classroom system which is mainly teacher-based learning. Memorization is encouraged rather than analytical or critical thinking. In Turkish Education System, school principals are appointed according to relative criteria from those who are successful in their duties as a teacher or vice principal. Despite the obvious warnings about appointment of the school principals the criteria haven't been stated concretely and the appointments have been made according to the very general qualification indicators as declared in the Law of Civil Servant, issued 657. The researcher, in addition to interviews, observed the woman principal for nearly a semester. Shortage of "permanent female principal" among the subject of the experiment forming the example has left no chance of choice to the researcher and thus she has had to be contented with a principal named Anne (psomodonious), the principal of the "Hope High School" and the results have been summarized below.
\end{abstract}

Keywords Portraying, Woman, School Principal, Turkey

\section{About Turkey}

Turkey stretches across Europe and Asia bridging the two continents geographically, economically and culturally. It is surrounded by the Black Sea in the north, the Marmara and the Aegean in the west, and the Mediterranean in the south. Its administration is made up of some 85 provinces and seven geographical regions, stretching across 780,452 kilometer squares of land surface. Its population is 85 million. The capital city is Ankara; the official language is Turkish; and the monetary unit is the Lira. Turkey, a modern and democratic state of law, located in a highly strategic geographical location, pursues an important role in the globalization process and continues to be an element of regional stability with its dynamic population and its growing economy.

Turkey is a state that geographically is divided between Europe and Asia. Turkey shares its borders with Syria, Iraq, Greece, Iran, Armenia, Azerbaijan, Bulgaria and Georgia. By looking at the geographical placement and Turkish history, Turkey appears to be a "melting pot" of ethnic groups and cultural influences.

Turkey has undergone a rapid economic, social and cultural development in the last century. Because of these rapid changes Turkey appears as a heterogeneous society; a society were traditions, values and lifestyles vary between the social classes, the urban and rural population and the secular and the religious segments of the society. Turkey is similar to other developing countries with respect to high internal migration from rural to urban areas, high population growth, high fertility rate and low life expectancy. Turkey is a secular country dominated by a Muslim population, $99 \%$, where the majority is Sunni Muslims.

\section{A Brief Look at the History of the Women's Movement in Turkey}

The structural changes that were to guide the modernization of the Ottoman State and its traditional foundations entered the national agenda during the II. Constitutional period of the late nineteenth century. The political structure of the empire consequently embarked on a centralization, secularization and liberation process. The impact of this modernization process was not confined to the Empire's political structure alone. All walks of life were affected. The status of Ottoman women began to change in line with this process as well.

The most significant indicators of the struggle action and demands of women are women's publications together with relevant information and documents during that period about women's association. Through the newspapers and periodicals of the period, women wrote of their problems and expectations and sought to promote social awareness raising, especially targeted towards other women. They organized conferences and formed associations where they took on active roles. Since the publication in 1869 of the first women's magazine "Progress of Civilizations", some 40 
women's periodicals were published until 1928 when the Republic adopted the Latin alphabet.

The magazines published and written by women aimed at creating an information network for and among women. The Women's World Magazine, a publication of the Ottoman Association for the Protection of Women's Legal Rights, on the other hand, espoused an explicitly feminist agenda. (The staff of this magazine, which patronized a female authorship only, was entirely composed of women).

This period also witnessed the birth of many women's organizations. They aimed at enhancing women's education, employment opportunities for women and promoting other women's issues such as modernization of clothing and attires. Some of these organizations were able to achieve great gains for women. For instance, the Ottoman Association for the Protection of Women's Legal Rights came out as one of the most radical activists of time. This association actively advocated for the employment of women in the civil service sector. As a result of this Association's broad based campaigning and advocacy, the Istanbul telephone company began to admit women. Likewise, the establishment of a university for women in 1914 resulted from the activism of this Association. In 1920, the students of the Women's University demonstrated in protest against discrimination in education, invaded the classrooms of men and demanded coeducation.

The War of Independence through 1919-1923 paved the way for significant changes to gender roles in Turkey. The conscription of men into the army combined with the shared struggle for independence led women taking over many of the roles ascribed to men. During the occupation of Istanbul, women demonstrated in protest; while, an Anatolian Women Association for National Struggle was established.

The Republican State in the post 1923 period made radical reforms for women. The Civil Code was adopted in 1926 and significantly raised the social status of women. The enhanced status of women was further confirmed with the granting of the right to vote and be elected.

Inspired not only by the UN declaration in 1975 of the Decade for Women, but also by the intensification of women's movements in West through the 1970s, women academics in Turkey began discussing women's issues in the late 1970s. A series of activities and demonstrations were held through 1982-1990, starting in the large cities. Following the weekly feminist discussion experience carried out in a national weekly magazine, women felt the need for their own independent publication and initiated the Women's Environment Book Club.

The next year a broad based campaign protested against domestic violence against women; and, women published a book titled Let Them Hear Your Scream which based on witness testimonies of domestic violence. Several feminist magazines began publication and women's movement gained the legitimacy and support of the public opinion thanks to women's demonstrations and their public repercussions.
The organized women's movement become a determinant and decisive factor in the observation of not only international programs and events such as the 8 March World Women's Day, but also in the realization of national panels, demonstrations, marches, and discussion meetings. In addition, the women's volunteer movement which continues work towards extension of women's shelters established the Foundation for Women's Library and Information Center which in turn opened up Turkey's first and only women's library.

\section{Professional Women in Turkey}

Professional women represent a rather small selection of the total female population in Turkey. This is illustrated by the fact that only 2.9 per cent of women in Turkey had the opportunity to attain a higher education in 2008. A university degree is still an opportunity only for the few. Due to specific historical and social structures in the Turkish society, the social-economical background of professional women had traditionally belonged to the middle-upper segments of the society. In the latter years however, there has been an increase in number of students at the universities. Women from different social backgrounds are starting to attend the universities to achieve a degree [21].

Turkish women in Turkey are still the main care-givers in the family, and carry the double burden of domestic and work related responsibilities. The Turkish State has developed few policies to ease the obstacles women meet in the labor market. Neither does the Turkish legal code have special laws to protect women at work from sexual harassment and discrimination [12].

Due to lack of formal support offered to working women in Turkey, it would be expected that this also would influence negatively the performance and work participation of professional women. Despite these obvious obstacles, professional women seem to not only hold full-time jobs, but also to succeed in areas where women are underrepresented in other countries [1].

Turkish women are hardly ever found in supervisory positions. The most they can become is a group leader and these positions only attained when the group entirely consists of women. Even this results in reservations on the part of the management, because of their view that workers do not obey a woman group leader. Employers are reluctant to appoint women as supervisors for two reasons. If the production unit consists of both female and male workers and the supervisor is a woman, it would not be appropriate for men to take orders from her; many employers argued that "men would not accept orders from a woman supervisor and would not behave respectfully" [16]. In Ecevit's [24] research she asked why women are not found in supervisory positions, they reply that women are more concerned with family problems and are more likely to leave work and it will not worth training women for higher positions or giving them supervisory jobs. She states that in almost all factories 
women work exclusively at the bottom of the hierarchy and the upper levels of the hierarchy are occupied by men. She also states that management and employers deliberately promote naturalistic assumptions about women's docility and submissiveness which reinforce the idea of patriarchal control; the more women are subject to the control, the more the firm will benefit.

Seyman [35] indicates that for many years the females are in a way "kept away" from high positions in management. This kind of glass ceiling was even recorded in some agreements. It is known that, in Turkey, it is more convenient for females to come to higher levels in public sector than they can in private sector.

Traditional Turkish culture exercises a strong influence on the Turkish family which remains very traditional in character and unquestionably accepts that women's roles are limited to those of mothers and wives [4, 19]. Women, nonetheless, have been able to change their traditional position and attain positions in society in which they can work for the betterment of their families. Women's involvement in the economy has been slow to catch on, though it still meets with resistance, at times [18].

Completion for formal urban jobs is likely to become more intense in the future since the current female participation is relatively low. Even though the participation of Turkish women in the formal labor market remains extraordinarily low [22], with Kazgan [31] reporting that women comprise only $11 \%$ of the urban labor force, competition for formal urban jobs has increased with rapid urbanization. As more men and middle class women enter the urban labor market, the squatter-house women have either withdrawn from the labor force or entered unspecialized branches to the urban sector.

\section{School Principalship in Turkey}

Turkey has a strong centralized education system in which all the decision-making is done by the Ministry of National Education. At the national level, the ministry prepares budgets, drafts educational legislation and formulates educational policy. It is responsible for the control, coordination and revision of education at all levels up to higher education including the provision of technical and vocational education. The state assumes the leading role in aggregating the resources and hiring the technical expertise to help plan, regulate, and manage the educational process [13].

Formal education programs at the primary and secondary level are the responsibility of the Ministry of Education. Formal schooling at the primary and secondary comprises an eight-year basic education, a five-year primary cycle and a three-year middle school cycle, and a three-year or four-year secondary education cycle. Formal educational or training institutes at the primary and secondary levels cannot be established without the approval of the Ministry of Education [15].
In Turkey the curriculum is coordinated by the Ministry of Education, and the same curriculum is used in every school for the entire country. The Ministry of Education has the authority to decide who will teach in different communities as well as designate the curriculum. It is mandated that all education must be in Turkish. Using the same curriculum and instructional strategies in every school is a limitation when you think about different learning styles of students, as all teachers use similar processing and teaching requirements regardless of the learners. Eight years of elementary education is obligatory for all girls and boys [7]. The education is mostly based on a traditional classroom system which is mainly teacher-based learning. Memorization is encouraged rather than analytical or critical thinking.

In Turkish Education System, school principals are appointed according to relative criteria from those who are successful in their duties as a teacher or vice principal [37]. However in educational institutions, school administrators are the ones, who organize, impress, guide, coordinate and inspect the staff in order to achieve the goals. Because of this, school administrators have to show some specific qualifications to fulfill their duties in line with the educational policies of Ministry of Education [29]. Besides, educational scientists believe that principals play an important role in the organization and operation of schools. Most of these experts consider principals as the main source and the driving force for the organizational development and academic growth of students [32]. On the one hand, principals combine the principalship with teaching, although the proportion of time spent on either role or duty depends on student and staff numbers at their school. When principals give up the principalship, they are immediately reassigned to teaching, having the same duties and rights as the rest of the teachers.

In the last several years the field of education has been the subject of nationwide reform movements. Principals are a crucial part of school improvement. Without effective principals, highly skilled teachers become frustrated, ineffective teachers stagnate and the resources of parents and community members go unused [30]. As a result, principals of today must be able to lead and instruct with veracity and quickness as they deal with the never ending tasks and interactions that come with the role [23].

Despite the obvious warnings about the qualities, training, problems and appointment of the school principals in the related literature, "the policy of training educational administrators couldn't have been carried out with regard to scientific basis for 30 years [9], administrator appointing criteria haven't been stated concretely and the appointments have been made according to the very general qualification indicators as declared in the Law of Civil Servant, issued 657. In Turkey, because of the common belief that there cannot be a school for managers, people haven't attach importance to training educational administrators for nearly a half century, authorities couldn't have taken the advantage of the graduates [5] in this system. 
As mentioned in the concerning part of the research, in order to have detailed information about a person or an organization the corporate application of a few different methods will increase the reliability of the data. This principle called triangulation in the literature is realized to ensure self-validity, and requires usage of multiple research methods to back up the results.

From this point, the researcher, in addition to interviews he made with the female she observed her for nearly a semester. Shortage of "permanent female principal" among the subject of the experiment forming the example has left no chance of choice to the researcher and thus she has had to be contented with a principal named Anne (psomodonious), the principal of the "Hope High School" and the results have been summarized below. The ability of the principal to manage the time, her leadership behaviors, her ability to solve problems and other notice-worthy aspects of her are the subjects that have been highlighted in the study. Doubtless, with only the help of these headings it is very difficult to draw an exact portrait of the principals but it is believed that they will help to be able make a comment about her to a great extent.

\section{A Portrait of the Principal}

Anne, a woman in her fifties and having two children has graduated from Open- University after a two year high school. During her professional career of 25 years she has worked as a principal for 12 years. Being constantly in an effort to renew herself she is a well-dressed woman who avoids conspicuous jewelries and wears a slight make-up and thus who can be presented as a role-model for woman teachers and students.

It is among the observations of the researcher that Anne is a person who deals not only with the physical content of the staff but with their psychological content as well, and who is obedient, moderate and avoids herself of extremities and who pays attention not to reflect her life and personal problems to the school. Besides this, it has been concluded that Anne is an experienced and self-confident person and a principal who is sensitive to her surrounding; who not only pays attention to the problems of the staff but also brings solutions to their problems as well.

According to the researcher, the principal pays a big effort to manage time most effectively. Because of being the principal of the school, having developed a method peculiar to herself, she comes earlier than the others do, and she goes straightly to her room, checks the 'things to do' list which she prepared the day before, completes the work left from past days, and arranges her duty in order of importance.

The principal classifies the files considering their degree of importance as: 'The files that can wait', 'the files that will be checked in my free time', 'the files that I should deal with in working-hours', 'the files that must be dealt with immediately'. For example in the file labeled as 'the file that can wait' are there invitation cards, festival cards, etc.
However in the file labeled 'do it immediately and answer' are there such official documents as documents of investigation or documents received from the national education directorate and must be replied on time or invoices.

The efficiency and beneficiality of the principal's filling method that she invented unintentionally and unconsciously is approved and backed up by the concerned filed of science. For example, in terms of managing time most effectively, Celikten [15] in his study 'a dairy of a principal' advises principals to plan a definite and personal calendar; and to develop a method that will help them leave work of less priority aside and use time most effectively. To the researcher mentioned, principals underline the need for advance decisively and courageously to make preferences, to determine priorities and to realize their decisions. Zel's [40] thoughts reveal similarity with Celikten's [15] study and with what the observed principal does. There is no research study that shows what the priorities have to be and every singly principal has to determine his peculiar priorities.

The principal of the school Anne, contrary to the expectations, spends most of her time in her office; prefers going to and checking such common places as classrooms, teachers' room, toilets, labs, workplaces etc. in case of obligation to visiting the regularly. For example, the principal has never attempted to have a chat with teachers or have a cup of tea with them in the teachers' room or participate in various activities held by the teachers.

Findings reveal contrast with the results of Pitner's research. Pitner [34] has determined that female school principals spend less time at desk than male ones do and is keener on visiting the classrooms or following the developments concerning the program or spending much more time dealing with their colleagues or supporting other woman. Besides they use a more prudent language. Ozden [33], making a research on effective principalship is of the opinion that the real place of a school principal is not his/her time in the classrooms or in the corridors will bring forward a new understanding and will give both teachers and students a message revealing what is important at that school. Balci [6] who also makes research of effective schools underlines the mere fact that school principals have to stop sitting at their desk and go out of their room and that the real job of a principal is to visit the teachers in the classrooms, and to walk around in the corridors and the classrooms, and is to be seen at the right place and time at school.

During the observations, the behaviors of the principal and her way of making decisions have been noted separately in order to have an impression regarding her management and leadership ability. According to the observations of the researcher, Anne, the school principal, gives much importance to equality; because she thinks everyone is equal, she acts by negotiating the staff, pays attention to their opinions. To the school principal, because the members of the staff participate in decision making, they approach the plans and its results with a sense of adaptation, meaning it enhances the chances of success and leaves no place for 
looking for a victim in case of unsuccessful applications and it also helps to take lessons from such situations.

The principal's making decisions by following the principal of participation gives way to her being criticized by especially her assistants. They criticize the principal for behaving over-sensitively at the meetings and describe her being highly expectant of the staff as 'waste of time'. One of the assistants of the principal blames her for being indecisive. $\mathrm{S} /$ he criticizes the principal with these words: 'She delays everything, and abstains from taking decisions or even lets the decisions come off by itself. She also thinks that the principal wants the group (staff) to come to a common decision cooperatively and that since every single member of the staff has a different point of view peculiar to him/her it becomes difficult to take a common decision.

Among the innumerable works of a principal, the most important one is 'how to make a decision.' Decision-making, more than being a characteristic of management is an element that forms a basis for all management activities. To Eren [25], decision-making and its being clear and easily understood is of the qualifications a principal is required to have. To Usta [38], successful principals take decisions that make impact, take the right steps at the right time, is aware of the fact that making hasty decisions means taking wrong decisions. And they make very few but fundamental decisions.

According to the observations of the researcher it has been observed that the principal has preferred not go over the problem has remained passive in solving the problem till the students and the staff are disturbed. Although it is not a healthy impression to make a generalization about a principal in just one semester, the views of the female assistant the principal works with justifies this judgment. To this female assistant, the school principal behaves more tolerant towards the male employees than she does towards female ones and gives them a message like this "I am the manager of this school meaning I have got the power.' [10].

In sum, continuing the effectiveness of the organization requires the problems being solved in the shortest time and with the most appropriate approach and way. In this context, one of the most important duties of a school principal is to produce effective solutions to the problems faced regarding the facilities and surroundings of the organization [11].

\section{The Turkish Education System}

Education in Turkey is compulsory for students ages six through 14. Pre-primary schooling is optional and can begin at age four. These schools consist mainly of games, theater, painting, singing, and learning manners. Only five to $10 \%$ of children attend pre-primary schools, and most come from families in big cities with working mothers. Primary Schooling begins at age seven and last for eight years. Teachers instruct the same group of students for all eight years of primary school. Because of the large population of school-age children, these schools are divided into two sessions. Children either attend morning or afternoon sessions in order to accommodate for the lack of teachers and building space. Each class has between 20 and 40 students, sometimes more in rural areas where schools are few and far between. Ninety-six percent of children attend primary schools. Many children in rural areas are unable to attend school because their families are physically unable to get their children to school due to their geographical location [41]. High school is optional for Turkish students. It usually lasts for three years, teaching students general knowledge while preparing them for higher education. One type of high school is the general high school, which $36.6 \%$ of the student-age population attends (MONE Directorate for Strategy Development, n.d.). The goal of these schools is "to secure a level of general knowledge, develop awareness of individual and community problems and to contribute to the economic, social and cultural growth of the country as well as preparing students for higher education" [8]. The second type of high school is the vocational and technical type. These schools train students for future jobs, as well as prepare them for higher education. Of the student-age population, $22.8 \%$ attend vocational and technical high schools [17].

Turkish education is regulated by the Ministry of National Education and Culture. Education is free until students reach the college or university level. Turkey is culturally and educationally considered to be a western nation. In the 1920s, Ataturk, the founder of the Republic of Turkey, helped to establish Turkey as a secular nation. He stated that the Turkish people needed to be education "to think freely and to have a free conscience" [36]. During this period, the Turkish alphabet changed from Arabic to Latin letters, an important factor in spreading education to the masses.

\section{Education Processes Affecting Girls' Education}

By law, girls and boys have had equal access to all levels of education since the inception of the Republic. Primary school is compulsory and further levels of education are left to the discretion of students and their families. In practice, however, the absence of an egalitarian approach to boys and girls and positive discrimination to balance the negative forces at play, tends to favour boys at all stages of education. The enrolment of the boy child is preferred to the girl child particularly in cases where a choice between the two has to be made. Traditional reluctance to send or keep the girl child in school still persists in the lower income bracket and rural areas [14].

Gender discrimination is frequently observed in the education processes as well. Elements such as teachers' background as well as their modes of socialisation and education usually prevent them from acquiring the necessary awareness to question what is traditional. Research indicates that teachers tend to overlook issues on whether or not their schools are male dominated or question the conservative and 
even gender biased content of textbooks and thus pay little attention to sexist approaches. The refusal to perceive gender segregation can be interpreted as an indication of the internalisation of traditional gender roles [26, 27, 38].

Another important factor in education processes regarding girls' education is the gender ratio of staff in schools. Only $3 \%$ of school principals in primary schools are women. Women constitute $44 \%$ of primary school teachers and $39 \%$ of secondary school teachers [20]. In universities, the gender gap is still greater. The prevalence of males in the upper echelons of education, teaching more 'important' subjects such as mathematics and physics enforces the message that higher levels of knowledge are the 'domain of men' while female teachers, more frequent in lower grades, are occupied in teaching subjects such as reading or writing [14].

\section{The Situation of a Woman in Administration of Education}

In Turkey, when, during the historical process, it has been carefully examined, the school-administrators have been chosen among the teachers of Ministry of Education, especially among men teachers. However, from 1998 some criteria have ben specified in the governing statutes broadcasted by Ministry of Education. At the results of changes on "training educational administrators, the giving importance the criterion of sufficiency" has given way for females to take place mare and more, in the position administrator. As male administrator used to be preferred in the appointments of school-director with the effect of society's view for female administrators was poorly positive. At least, the lucks of male and female teachers' in appointments for school-director have become equal [3]. Among the ones in the position of Educational administrators "the percentage of females becoming low" can be pointed as a reason of positive prejudice for women to become administrators. According to the data of 2016 it has obviously seen that eight percent of school-masters, and twenty percent of assistant directors are women [42].

There has officially been no obstacles on women's appointments to become administrators to the enact regulations published by Ministry of Education. In Turkey, men and women have the same chance on becoming administrator. Even, it is found out that women have the priority. Although this, at the back of some situations like women's becoming fewer than men in number and their not preferring administration lies raised from themselves and their environments. In Celikten's [14] study relevant to women administrators, the women whom he interviewed have given information on two points which were "the questions they faced and executive profiles of women administrators in Turkey. According to the research findings; while entering school management as it is thought, but not gender discrimination applied; mostly women's not preferring willingly to become administrators; in the proportion of women who applied to enter exams (open to all teachers, both men and women) of administration which is only ten percent in itself, the success of the examination participants being low at the same way; a lot of female teachers succeeded in the programme of "in service administration" are still preferring to work as teachers draw attention.

Also, in his research a woman schol-director was observed, and Celikten [15] tried to identify how many her duties and responsibilities coincided with her activities. According to the findings obtained by using observation technics; the school-director chosen as a tested, has been spending her time outside of her room she, so to speak, has been directing the school while walking around. The observed director's duties have changed in-more often- density during the day, both formally and informally she was interrupted by complaints and wanting short-termed or she continued to her duty in the roles of instructional leadership, mediator, teacher problem solver: and it was understood that she continuously had experienced exchange.

\section{The Learning Environment for Girls}

The learning environment for girls has various dimensions. Although systematic data regarding the psychological environment for girls is not available, numerous researches and observations provide an overall idea of the implications. School as a psychological environment is by nature a stressful place for students where they are subject to the control of authority not only in the process of learning but also in the details of their personal appearance such as fingernails, hair, clothes, inter-student relationships and so forth. Girls especially are under meticulous surveillance by teachers who frequently add further limitations on loudness of speech, manners \&c. Consequently girls tend to refrain from asking questions or contributing to discussions and decisions in order to minimise the risk of attracting attention -- at the same time they also inhibit the necessary interaction required for efficient learning. As a result of this strategy girls have less discipline problems but they also tend to volunteer more in accordance with gender expectancies for cleaning, services, solidarity in extra-curricular activities \&c., -- especially in rural areas [2].

In general schools have negligible safety and security problems. Major physical upgrading activities have been undertaken to meet the building standards of MONE, yet continued efforts are necessary [4]. The learning environment is not confined to school buildings alone: there are schools in the outskirts of urban areas and in some rural areas which are difficult to reach particularly in the winter. However, State provision of bus services to schools further than $2.5 \mathrm{~km}$ has improved the access of girls to school. Regional boarding schools are another positive application to minimise the negative effects of long travelling distances. 


\section{REFERENCES}

[1] Acar, F. (1994). "Women and Higher Education in Turkey: A Golf Bracelet for Women." In The Gender Gap in Higher Education. Lie, S. and Harris, D. (Eds.), London: Kogan Page.

[2] Acar, F, Ayata, A.G. \& Varoğlu, D. (1999). Gender Discrimination: Examples from Turkey's Education Sector, (Ankara: GDSPW).

[3] Altınışık, S. (1999). On Yı1 Öncesine Kıyasla Öğretmenlerin Okul Müdürlüğündeki Sayısal Azlığının Görünümü. 4.Ulusal Eğitim BilimleriKongresi Bildirileri, Anadolu Üniversitesi Eğitim Fakültesi Yayını, 51, 94-107.

[4] Asar, R. \& Çelikten, M. (2016). Evaluation of the attitudes towards women managers working at educational institutions. OPUS - Uluslararası Toplum Araştırmaları Dergisi, 6(10), 8-19.

[5] Ağaoğlu, E., Gültekin, M., \& Çubukçu, Z. (2002). Okul yöneticisi yeterliklerine dayalı eğitim programı önerisi. 21. Yüzyıl Eğitim Yöneticilerinin Yetiştirilmesi Sempozyumu Bildirileri, 145-161.

[6] Balc1, A. (2002). Türkiye’de Eğitim Yöneticilerinin Yetiştirilmesi. 21. Yüzyıl Eğitim Yöneticilerinin Yetiştirilmesi Sempozyumu Panel Üyeliği, Ankara Üniversitesi, ATAUM, Ankara.

[7] Bayram, S. \& Seels, B. (1997). The utilization of instructional technology in Turkey, Educational Technology Research and Development, 45 (1), 112-121.

[8] Can, N. \& Çelikten, M. (2000). Alt Düzey Personelin Güç Kaynakları Erciyes Üniversitesi Örneği. Kuram ve Uygulamada Eğitim Yönetimi, 22(22), 269-290.

[9] Çelik, V. (2002). Eğitim yöneticisi yetiştirme politikasına yön veren temel eğilimler. 21. Yüzyıl Eğitim Yöneticilerinin Yetiştirilmesi Sempozyumu, 3-12.

[10] Çelikten, M. (2001a). Okul Yöneticilerinin Problem çözme becerileri. Kuram ve Uygulamada Egitim Yönetimi Dergisi, 7(3), 297-309.

[11] Çelikten, M. (2001b). Etkili okullarda karar süreci. Erciyes Üniversitesi Sosyal Bilimler Enstitüsü Dergisi, 11(2), 263-274.

[12] Çelikten, M. (2003). Okul Kültürünün Şekillendirilmesinde Müdürün Rolleri. Türk Eğitim Bilimleri Dergisi, 1(4).

[13] Çelikten, M. (2004a). İdeal Bir Okul Müdürü Portresi. Akademik Araştırmalar Dergisi, 21, 195-204.

[14] Çelikten, M. (2004b). Okul Müdürü Koltuğundaki Kadınlar: Kayseri ili örneği. Sosyal Bilimler Enstitüsü Dergisi, 17(2), 91-118.

[15] Çelikten, M. (2004c). Bir Okul Müdürünün Günlüğü. Firat Üniversitesi Sosyal Bilimler Dergisi, 14(1), 123-135.

[16] Çelikten, M. \& Yeni, Y. (2004). Okul Müdürlerinin Liderlik ve Yöneticilik Özelliklerinin Cinsiyet Açısından Değerlendirilmesi. Kastamonu Eğitim Dergisi, 12(2), 305-314.

[17] Çelikten, M. (2005). Neden İş Analizi Yapılmalı? Sosyal Bilimler Enstitüsü Dergisi, 18(1), 127-135.
[18] Çelikten, M., Şanal, M. \& Yeni, Y. (2005). Öğretmenlik Mesleği ve Özellikleri. Erciyes Üniversitesi Sosyal Bilimler Enstitüsü Dergisi, 19(2), 207-237.

[19] Celikten, M. (2006). Kültür ve Öğretmen Metaforları. Sosyal Bilimler Enstitüsü Dergisi, 21(2), 269-283.

[20] Çelikten, M. \& Çelikten, Y. (2007). Televizyon Programlarında Çizilen Öğrenci, Öğretmen ve Yönetici Profilleri. Sosyal Bilimler Enstitüsü Dergisi, 23(2), 369-378.

[21] Çelikten, M. (2008). Öğretmenlik Mesleğinde Yeni Model Arayıșları. Selçuk Üniversitesi Sosyal Bilimler Enstitüsü Dergisi, 19, 189-195.

[22] Çelikten, M. (2010). Okul Örgütü ve Yönetimi, V. Çelik (Ed.), Türk eğitim sistemi ve okul yönetimi (s. 121-140). Ankara: Pegem Akademi.

[23] DePaola, M. \& Tschanned-Moran, M. (2003). The principalship at a crossroads: A study of the conditions and concerns of principals, Bulletin, 87 (634), 43-65.

[24] Ecevit, Y. (1991). Shop floor control: The ideological construction of Turkish women factory workers. In $\mathrm{N}$. Redclift and M. Sinclair (Eds.), Working Women: International Perspectives on Labour and Gender Ideology, (New York: Routledge).

[25] Eren, E. (1996). Management and Organization (Istanbul: Beta Publishing).

[26] Gök, F. (1995). Education and Women in Turkey. In Tekeli, Ş. (Ed.), The Woman's Point of View on Women in Turkey in the 1980's (İstanbul: İletisim Publishing).

[27] Gök, F. \& Okçabol, R. (1999) Teacher Profiling Research Report, (İstanbul: Eğitim Sen).

[28] Gursel, M. (1995) School Administration, (Konya: Inci Publishing).

[29] Gürsel, M. (2003). Eğitim yöneticisinin yeterlikleri. (Konya: Eğitim Kitabevi).

[30] Jones, R. (1995). Picturing your perfect principal, The executive educator, 17 (2), 516-521.

[31] Kazgan, G. (2002). 1990 sonrası yıllarda Türkiye'de Krizler ve İşsizlik; Çalışanlar ve Sosyal Güvenlikleri için Çözümler Açısından bir İrdeleme.

[32] Mirkamali, M. (1995). Educational management and leadership. Tehran: Ramin Publication.

[33] Özden, Y. (1998). Eğitimde dönüşüm, yeni değer ve oluşumlar. Ankara: Pegem Yayımcılık.

[34] Pitner, N. (1981). Hormones and Harems: Are the Activities of Superintending Different for a Woman? in P. Schmuck et al. Educational Policy and Management: Sex Differentials (New York: Academic Press).

[35] Seyman, Y. (1992). Kadın ve sendika. SD Yayınları, (Sosyal Demokrasi Yayınları).

[36] Sevinç, M. (2006). Evrensel ve yerel değerlerin eğitime yansımaları.Küreselleşme Ahlâk ve Değerler.(Ed. Yurdagül Mehmedoğlu ve Ali Ulvi Mehmedoğlu). Littera Yayıncılık: İstanbul. 
[37] Taymaz, H. (1995) School Administration, (Ankara: Saypa).

[38] Türkoğlu, H, (1999). Women Teachers and Trade Union Participation Examples of Eğitim Sen, (Master thesis, Ankara University, Turkey).

[39] Usta, R. (2001). Zaman Yönetimi ve Yöneticilerin Zamanı Kullanma Biçimleri. Standard Ekonomik ve Teknik Dergisi,
Y11, 40, 75-80.

[40] Zel, U. (2002). İş arenasında kadın yöneticilerin algılanması ve kraliçe arı sendromu. Türkiye ve Ortadoğu Amme daresi Dergisi, 35, 2.

[41] http://www.enjoyturkey.com/

[42] http://kadininstatusu.aile.gov.tr/uygulamalar/turkiyede-kadin 